\title{
HOW I CAME TO BE ASSOCIATED WITH KRITIKA KULTURA
}

\author{
Rajeev S. Patke \\ Yale-NUS College \\ National University of Singapore
}

The story of my association with Kritika Kultura starts off with Lily Rose Tope, whom I knew ever since she did her doctoral work at the National University of Singapore, and who I would meet, along with many other academic colleagues from SE Asia, at international conferences organized regularly by the wonderful Professor Wolfgang Zach, to whom I had been introduced by poet and then Dean of the Faculty of Arts and Social Sciences at the National University of Singapore, Edwin Thumboo. At one such conference, soon after the publication of my book, Postcolonial Poetry in English (Oxford UP, 2006), Lily asked me if the Philippines figured in my book, given its history of American colonialism. I had to confess then that my book had focused largely on poetry from the former colonies of Britain (and other European nations). I then promised Lily that if I did undertake another book, I would make amends for my lack of knowledge about Filipino writing. I meant it, and set about planning a literary history of writing in English from Southeast Asia. The plan developed smoothly, and I started work on such a book with my colleague at NUS, Philip Holden. We did two things: approach a publisher (Routledge) with a view to securing a contract, and set to work reading intensively in the literatures in English from Singapore, Malaysia, and the Philippines, as well as Hong Kong, and other countries in the region with a minor tradition in English writing. At about the same time I approached the National Library Board of Singapore with a view to planning an anthology of SE Asian writing in English: money was secure for that and a large anthology, titled Southeast Asian Writing in English: A Thematic Anthology, edited by me, Philip Holden, Lily Rose-Tope, and Isabela Mooney-Banzon was published eventually in 2012. But well before that, Philip and I had secured a small amount of research founding at NUS and began a series of trips to the Philippines, spending many hours meeting academics and writers in Manila and spending even more hours at the excellent libraries 
there, hosted most graciously by Lily, Isabel, and Lulu Reyes, whose acquaintance I made at one such visit. I discovered many Filipino journals, was bowled over by the amazing productivity of writers in the Philippines, and started presenting conference papers and publishing articles on writers from SE Asia. Lulu invited me to give a talk on postcolonial literatures, and in the process of writing the book with Philip, I began an enduring interest in writings from the Philippines, which was further cemented by an invitation by Lulu to join the editorial board of Kritika Kultura and by my friendship with Vince Serrano, whom I first met at a conference organized by Lily, and whom I then co-supervised for part of his doctoral work in the UK, where his and my admiration for Nick Joaquin intersected with our aiding interest in the ideas of Walter Benjamin. The book jointly authored by me and Philip, The Concise Routledge History of Southeast Asian Writing in English was completed in 2009 and published in 2010. I continue to read writings from the Philippines, always amazed at its energy and linguistic brio. It is an honor for me to be associated with a journal as acutely responsive to the literary climate of the Philippines as Kritika Kultura. 